\title{
Evaluation of processed rubber seed oil Hevea brasiliensis utilization as lipid source in Clarias gariepinus feed
}

\section{Evaluasi pemanfaatan minyak biji karet Hevea brasiliensis yang telah diproses sebagai sumber lemak pada pakan ikan lele Clarias gariepinus}

\author{
Nuraini Annisa', Muhammad Agus Suprayudii*, Mia Setiawati', Ichsan Ahmad Fauzi ${ }^{1}$ \\ ${ }^{1}$ Department of Aquaculture, Faculty of Fisheries and Marine Sciences, IPB University, \\ Bogor-Indonesia \\ *Corresponding author: muhammadsu@apps.ipb.ac.id
}

(Received November 21, 2019; Accepted January 21, 2020)

\begin{abstract}
Clarias gariepinus rearing is mostly done with intensive systems that use a lot of commercial feed. The price of raw material for the feed lipid source which is currently the main source of fatty acids in freshwater fish feed continues to increase and compete with human needs. Rubber seed oil (RSO) is considered feasible to be an alternative. This study aimed to evaluate the use of heated RSO as alternative lipid source in C. gariepinus feed. The results of this study indicated that heating could reduce HCN levels in RSO by $95 \%$. Even after heated RSO was inserted into the feed formulation there is still $\mathrm{HCN}$ in feed, however it did not affect the survival rate of $C$. gariepinus statistically. Heated RSO based feed shows a specific growth rate that was higher than non-heating RSO-based feed. Feeding with heated RSO also did not affect nutrient retention in $C$. gariepinus. This also followed by blood profile, blood chemistry and body fatty acids profile, MDA levels and SOD levels which were almost same as treatment feed using fish oil and corn oil. From these results, it can be concluded that heating can reduce $95 \%$ HCN content in $\mathrm{RSO}$ and can be used as a lipid source in C. gariepinus feed.
\end{abstract}

Keywords: Aquaculture, essential fatty acids, growth performance, HCN, rubber seed oil.

\begin{abstract}
ABSTRAK
Budidaya ikan lele Clarias gariepinus dengan sistem intensif menggunakan banyak pakan buatan. Harga bahan baku untuk sumber lemak pakan terus meningkat dan bersaing dengan kebutuhan manusia. Minyak biji karet (MBK) layak menjadi alternatif. Penelitian ini bertujuan mengevaluasi penggunaan MBK yang dipanaskan sebagai sumber lemak alternatif dalam pakan ikan lele. Hasil penelitian menunjukkan proses pemanasan dapat mengurangi kadar HCN pada MBK hingga 95\%. Walaupun masih terdapat sejumlah kecil HCN pada pakan berbasis MBK yang dipanaskan, tetapi tidak memengaruhi tingkat kelangsungan hidup ikan lele $(\mathrm{P}>0,05)$. Pakan berbasis $\mathrm{MBK}$ proses pemanasan menunjukkan laju pertumbuhan spesifik yang lebih tinggi dari pakan berbasis MBK yang tidak dipanaskan. Pemberian pakan berbasis MBK proses pemanasan juga tidak memengaruhi retensi nutrisi ikan lele. Demikian pula parameter profil darah, kimia darah, profil asam lemak tubuh, kadar MDA dan kadar SOD hampir sama dengan pakan perlakuan berbasis minyak ikan dan minyak jagung. Sehingga dapat disimpulkan MBK proses pemanasan dapat mengurangi 95\% kandungan HCN dan dapat digunakan sebagai sumber lemak dalam pakan ikan lele.
\end{abstract}

Kata kunci: Akuakultur, asam lemak esensial, $\mathrm{HCN}$, kinerja pertumbuhan, minyak biji karet. 


\section{INTRODUCTION}

According to KKP (2017), national production of Clarias gariepinus in 2017 reached 1.095 .969 tons and up to early 2018, it reached 531.521 tons. C. gariepinus rearing is mostly done with an intensive system culture that requires artificial feed. One important component as energy and essential fatty acids source in fish feed is lipid (Orsavova et al., 2015). Vegetable oils, such as corn oil, canola oil, and palm oil are the main sources of vegetable fatty acids in freshwater fish feed (Ortiz et al. 2017; Shahrooz et al. 2018). Unfortunately, along with the increase in the price of vegetable oil and competition with human needs, a more economical alternative of lipid sources that contains adequate essential fatty acid content is needed.

Data from the Directorate General of Plantations (2010); Widyarani et al. (2014) said, Indonesia has around 3.3 million hectares of rubber plantations which can produce around 4 million tons of rubber seeds per year but have not yet been fully utilized. Processed rubber seed meal can be used as a protein source in fish feed (Syamsunarno \& Sunarno, 2014), such as in pangasius (Suprayudi et al., 2014), carp (Suprayudi et al., 2015), and tilapia (Yusuf et al., 2016). Rubber seeds contain 50-60\% rubber seeds oil (RSO) (Kumar \& Sharma, 2011). According to Salimon et al. (2012) RSO has $37.28 \%$ of linoleic acid (LA 18:2n-6) and $19.22 \%$ of linolenic acid (LNA 18:3n-3). RSO has greater LNA content than similar vegetable oils, such as corn oil $(0.023-0.39 \%)$ and palm oil $(0.08-0.23 \%)$. It also has LA content which is fairly similar to corn oil (45.92-54.21\%) (Hwang, 2009; Dowd et al., 2010; Bami et al., 2017).

Hydrogen cyanide $(\mathrm{HCN})$ is a limiting factor in RSO utilization. Each kilogram of rubber seeds contained about $1.64 \mathrm{~g} \mathrm{HCN}$ (Widyarani et al., 2016). Salimon et al. (2012) stated that HCN is classified as a chemical compound that is unstable to heat, so that the physical treatment of heating can evaporate HCN. Therefore, this study used RSO which has been through physical treatment in the form of heating with a temperature of $100^{\circ} \mathrm{C}$ as an intention to reduce HCN levels in the RSO.

\section{MATERIALS AND METHODS}

\section{Rubber seed oil (RSO) preparation}

Rubber seeds were obtained from a rubber plantation in Setu Village, Jasinga, Bogor, West
Java. To get RSO, rubber seeds are pressed using hydrolic pressure at $80^{\circ} \mathrm{C}$ with a pressure of 8 bar for 15 minutes. RSO then given $500 \mathrm{mg} / \mathrm{L}$ TN Ox as an antioxidant. Some RSO then heated in an oven at $100^{\circ} \mathrm{C}$ for 60 minutes (Zhang et al., 2013). RSO with and without heating were analyzed for HCN content, peroxyde number and free fatty acids (AOAC, 2012). The HCN and peroxyde value (POV) content of RSO with and without heating are presented in Table 1 and fatty acids profiles are presented in Table 2.

Table 1. Hydrogen cyanide ( $\mathrm{HCN})$ and peroxyde value (POV) content in rubber seed oil with and without heating.

\begin{tabular}{ccc}
\hline $\begin{array}{c}\text { Heating duration } \\
\text { (minutes) }\end{array}$ & HCN (mg/L) & POV (meq/kg) \\
\hline 0 & 44.87 & 4.63 \\
60 & 2.02 & 1.97 \\
\hline
\end{tabular}

Table 2. Heated rubber seed oil and rubber seed oil without heating fatty acids profile.

\begin{tabular}{ccc}
\hline Fatty acids & $\begin{array}{c}\text { Heated } \\
\text { rubber seed } \\
\text { oil }(\%)\end{array}$ & $\begin{array}{c}\text { Rubber seed oil } \\
\text { without heating } \\
(\%)\end{array}$ \\
\hline$\sum$ SFA* & 17.79 & 22.81 \\
$\sum$ MUFA* & 23.17 & 22.18 \\
$\sum$ PUFA* & 57.71 & 53.76 \\
18:2n-6 & 40.01 & 37.45 \\
(Linoleic) & & 16.3 \\
18:3n-3 & 17.6 & 0 \\
(Linolenic) & 0 & 0.1 \\
20:4n-6 (AA)* & 0.01 & 0 \\
20:5n-3 (EPA)* & & \\
22:6n-3(DHA)* & 0 & \\
\% sample fatty acids: \% area x \% sample lipid. \\
*SFA: saturated fatty acid; MUFA: monosaturated \\
fatty acid; PUFA: polyunsaturated fatty acid; AA: \\
$\begin{array}{l}\text { arachidonic acid; EPA: eichosapentainoic acid; DHA: } \\
\text { docosahexanoic acid. }\end{array}$
\end{tabular}

\section{Experimental design}

The experimental design in this study was a one-factor randomized complete design (CRD). This experiment consisted of five treatments and was repeated three times, so that 15 treatment units were obtained. Test feeds were isocalories and isoproteins. The combination of feed lipid sources given are as follows (Table 3):

\section{Experimental diets}

The tested feed used in this study originated from different lipid source. Feed raw materials 
Table 3. Experimental design

\begin{tabular}{cc}
\hline Treatment & Dossage \\
\hline CPO:FO* & Feed with 50\% palm oil $+50 \%$ fish oil \\
CPO:CO* & Feed with 50\% palm oil $+50 \%$ corn oil \\
CPO:RSOH* & Feed with $50 \%$ palm oil $+50 \%$ RSOH \\
PRSO* $^{*}$ & Feed with $100 \%$ RSOH \\
URSO* & Feed with $100 \%$ RSO \\
\hline
\end{tabular}

*CPO:FO : 50\% palm oil + 50 \% fish oil; CPO:CO: $50 \%$ palm oil + 50\% corn oil; CPO:RSOH: $50 \%$ palm oil + 50\% RSOH; PRSO: 100\% RSOH; URSO:100\% RSO.

*CPO: crude palm oil; FO: fish oil, CO: corn Oil; RSOH: heated rubber seed oil; RSO: unheated rubber seed oil; PRSO: $100 \%$ rubber seed oil with heating; URSO: $100 \%$ rubber seed oil without heating.

Table 4. Feed formulation, proximate, and HCN levels.

\begin{tabular}{|c|c|c|c|c|c|}
\hline \multirow{2}{*}{ Ingredients (\%) } & \multicolumn{5}{|c|}{ Experimental diets } \\
\hline & CPO:FO* & $\mathrm{CPO}: \mathrm{CO}^{*}$ & $\mathrm{CPO}: \mathrm{RSOH}^{*}$ & PRSO* & URSO* \\
\hline Fish meal & 6.5 & 6.5 & 6.5 & 6.5 & 6.5 \\
\hline Poultry by-product meal & 16.5 & 16.5 & 16.5 & 16.5 & 16.5 \\
\hline Soybean oil & 24.0 & 24.0 & 24.0 & 24.0 & 24.0 \\
\hline Pollard & 30.0 & 30.0 & 30.0 & 30.0 & 30.0 \\
\hline Wheat flour & 18.8 & 18.8 & 18.8 & 18.8 & 18.8 \\
\hline Fish oil Chum salmon $\left(\right.$ Tassal $\left.{ }^{\odot}\right)$ & 1.0 & - & - & - & - \\
\hline Corn oil & - & 1.0 & - & - & - \\
\hline Palm oil & 1.0 & 1.0 & 1.0 & - & - \\
\hline Heated rubber seed oil & - & - & 1.0 & 2.0 & - \\
\hline Rubber seed oil & - & - & - & - & 2.0 \\
\hline Premix** & 2.2 & 2.2 & 2.2 & 2.2 & 2.2 \\
\hline Total & 100.0 & 100.0 & 100.0 & 100.0 & 100.0 \\
\hline \multicolumn{6}{|l|}{ Feed proximate } \\
\hline Protein \% & 30.34 & 30.09 & 30.17 & 30.52 & 30.44 \\
\hline Lipid (\%) & 5.27 & 5.33 & 5.43 & 5.24 & 5.37 \\
\hline Moisture (\%) & 8.09 & 8.47 & 7.96 & 8.18 & 8.89 \\
\hline Ash (\%) & 9.13 & 8.94 & 8.15 & 8.01 & 9.13 \\
\hline Crude fibre $(\%)$ & 5.14 & 5.98 & 4.89 & 5.89 & 5.74 \\
\hline Free extract nitrogen $(\%)$ & 42.03 & 40.38 & 43.4 & 42.16 & 40.43 \\
\hline $\mathrm{GE}^{* * *}(\mathrm{kkal} / \mathrm{g})$ & 3959.62 & 3927.38 & 4022.57 & 3972.46 & 3907.48 \\
\hline $\mathrm{HCN}(\mathrm{mg} / \mathrm{L})$ & - & - & 1.35 & 1.77 & 7.92 \\
\hline \multicolumn{6}{|c|}{ 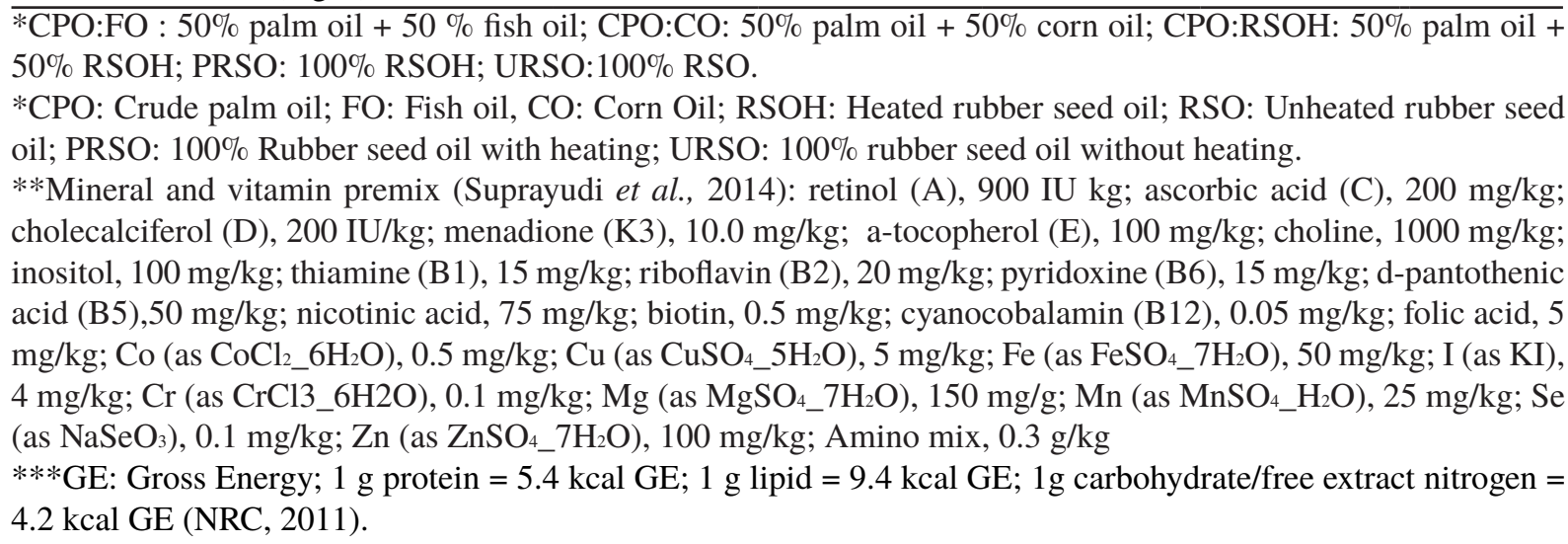 } \\
\hline
\end{tabular}


Table 5. Feed fatty acids composition.

\begin{tabular}{cccccc}
\hline \multirow{2}{*}{ Fatty acids (\%) } & \multicolumn{5}{c}{ Experimental diets } \\
\cline { 2 - 6 } & CPO:FO* & CPO:CO* & CPO:RSOH* & PRSO* & URSO* $^{*}$ \\
\hline$\sum$ SFA $^{* *}$ & 1.89 & 2.05 & 1.89 & 1.92 & 1.68 \\
$\sum$ MUFA $^{* *}$ & 2.34 & 1.56 & 1.76 & 1.57 & 1.60 \\
LPUFA** & 1.06 & 1.72 & 1.80 & 1.76 & 2.11 \\
18:2n-6 (Linoleic acid) & 0.34 & 1.53 & 1.28 & 1.29 & 1.56 \\
18:3n-3 (Linolenic acid) & 0.60 & 0.16 & 0.33 & 0.44 & 0.50 \\
20:4n-6 (AA)** & 0.02 & 0.00 & 0.00 & 0.00 & 0.00 \\
20:5n-3 (EPA)** & 0.02 & 0.00 & 0.00 & 0.00 & 0.00 \\
22:6n-3(DHA)** & 0.03 & 0.00 & 0.00 & 0.00 & 0.00 \\
\hline
\end{tabular}

*CPO:FO : $50 \%$ palm oil + 50 \% fish oil; CPO:CO: $50 \%$ palm oil + 50\% corn oil; CPO:RSOH: $50 \%$ palm oil + 50\% RSOH; PRSO: $100 \%$ RSOH; URSO: $100 \%$ RSO.

*CPO: Crude palm oil; FO: Fish oil, CO: Corn Oil; RSOH: Heated rubber seed oil; RSO: Unheated rubber seed oil; PRSO: 100\% Rubber seed oil with heating; URSO: 100\% rubber seed oil without heating.

**SFA: Saturated fatty acid; MUFA: Monosaturated fatty acid; PUFA: Polyunsaturated fatty acid; AA: Arachidonic acid; EPA: Eichosapentainoic acid; DHA: Docosahexanoic acid.

Table 6. Growth and feed performance of Clarias gariepinus fed with different lipid sources

\begin{tabular}{|c|c|c|c|c|c|}
\hline \multirow{2}{*}{ Parameters } & \multicolumn{4}{|c|}{ Experimental diets } & \multirow[b]{2}{*}{ URSO* } \\
\hline & CPO:FO* & CPO:CO* & CPO:RSOH* & PRSO* & \\
\hline $\begin{array}{l}\text { Feed intake } \\
(\mathrm{g})\end{array}$ & $1796.94 \pm 68.75^{\mathrm{a}}$ & $1761.13 \pm 162.06^{\mathrm{a}}$ & $1866.07 \pm 105.36^{a}$ & $1787.49 \pm 57.98^{\mathrm{a}}$ & $\begin{array}{c}2183.49 \pm \\
123.03^{\mathrm{b}}\end{array}$ \\
\hline FCR & $1.16 \pm 0.03^{\mathrm{a}}$ & $1.12 \pm 0.09^{\mathrm{a}}$ & $1.15 \pm 0.06^{\mathrm{a}}$ & $1.10 \pm 0.07^{\mathrm{a}}$ & $2.16 \pm 0.13^{b}$ \\
\hline SGR (\%) & $4.69 \pm 0.06^{\mathrm{b}}$ & $4.71 \pm 0.05^{\mathrm{b}}$ & $4.70 \pm 0.13^{\mathrm{b}}$ & $4.56 \pm 0.08^{\mathrm{b}}$ & $2.23 \pm 0.7^{\mathrm{a}}$ \\
\hline $\begin{array}{l}\text { Protein } \\
\text { retention } \\
(\%)\end{array}$ & $50.21 \pm 0.79^{a}$ & $51.14 \pm 4.23^{\mathrm{a}}$ & $50.25 \pm 2.88^{\mathrm{a}}$ & $53.07 \pm 3.59^{a}$ & $26.34 \pm 0.96^{\mathrm{b}}$ \\
\hline $\begin{array}{l}\text { Lipid } \\
\text { retention } \\
(\%)\end{array}$ & $119.90 \pm 4.55^{\mathrm{a}}$ & $122.85 \pm 9.41^{\mathrm{a}}$ & $116.73 \pm 6.10^{a}$ & $125.93 \pm 8.82^{\mathrm{a}}$ & $65.10 \pm 4.85^{\mathrm{b}}$ \\
\hline SR $(\%)$ & $100 \pm 0.00^{\mathrm{b}}$ & $97.78 \pm 3.85^{\mathrm{b}}$ & $95.56 \pm 3.85^{\mathrm{b}}$ & $88.89 \pm 3.85^{\mathrm{b}}$ & $35.56 \pm 13.88^{\mathrm{a}}$ \\
\hline $\begin{array}{l}\text { *CPO:FO : } 5 \\
50 \% \text { RSOH; } 1 \\
{ }^{*} \text { CPO: Crude } \\
\text { oil; PRSO: } 10 \\
\text { SE }(n=3) . \mathrm{V} \\
\text { FCR: Feed co }\end{array}$ & $\begin{array}{l}\text { palm oil + } 50 \% \\
\text { SO: } 100 \% \text { RSOH } \\
\text { alm oil; FO: Fish } \\
\text { to Rubber seed oil } \\
\text { es that share diffe } \\
\text { ertion ratio; SGR }\end{array}$ & $\begin{array}{l}\text { fish oil; CPO:CO: } \\
\text {; URSO: } 100 \% \text { RSC } \\
\text { oil, CO: Corn oil; } \\
\text { with heating; URSC } \\
\text { rent letters in the sa } \\
\text { Specific growth ra }\end{array}$ & $\begin{array}{l}\% \text { palm oil }+50^{\circ} \\
\text { OH: Heated rubb } \\
100 \% \text { rubber seec } \\
\text { column are sign } \\
\text {; SR: Survival rat }\end{array}$ & $\begin{array}{l}\text { orn oil; CPO:RS } \\
\text { seed oil; RSO: U } \\
\text { 1 without heating } \\
\text { antly different (D }\end{array}$ & $\begin{array}{l}\text { I: } 50 \% \text { palm oil }+ \\
\text { eated rubber seed } \\
\text { alues are means } \pm \\
\text { can test; } \mathrm{P}<0.05)\end{array}$ \\
\hline
\end{tabular}

were tested for proximate before formulation. The raw materials were combined using a mixer until it was homogeneous then printed using $2 \mathrm{~mm}$ diameter feed molding machine and dried with an oven at $40^{\circ} \mathrm{C}$. Dry feeds were tested for proximate and HCN levels. Proximate and HCN analysis referred to AOAC (2012). Proximate values and feed HCN levels are presented in Table 4.

The use of different feed lipid sources will affect the fatty acids feed composition. Therefore, it was necessary to test the composition of feed fatty acids. The feed fatty acids composition are presented (Table 5).

\section{Research procedures}

This research was conducted from February to August 2019 which included the process of preparation for tested feed, fish maintenance, and final test results. The process of making test feed and maintaining fish was carried out in the Teaching Farm and the final test results were conducted at Fish Nutrition Laboratory, Department of Aquaculture, Faculty of Fisheries and Marine Sciences, IPB University, Bogor.

\section{Rearing conditions}

The fish being tested was Clarias gariepinus 
Table 7. Clarias gariepinus body fatty acids that are fed with different lipid sources

\begin{tabular}{|c|c|c|c|c|c|c|}
\hline \multirow{2}{*}{ Fatty acids } & \multirow{2}{*}{ Unit } & \multicolumn{5}{|c|}{ Experimental diets } \\
\hline & & CPO:FO* & CPO:CO* & CPO:RSOH* & PRSO* & URSO* \\
\hline$\Sigma \mathrm{SFA}^{* *}$ & $\%$ & $31.43 \pm 0.48^{\mathrm{a}}$ & $37.22 \pm 0.48^{\mathrm{b}}$ & $37.68 \pm 0.72^{b}$ & $37.00 \pm 0.12^{\mathrm{b}}$ & $37.82 \pm 0.75^{\mathrm{b}}$ \\
\hline$\Sigma \mathrm{MUFA}^{* *}$ & $\%$ & $28.51 \pm 0.61^{\mathrm{a}}$ & $33.65 \pm 1.08^{c}$ & $30.62 \pm 1.11^{\mathrm{ab}}$ & $31.81 \pm 1.60^{\mathrm{bc}}$ & $32.88 \pm 1.56^{\mathrm{a}}$ \\
\hline$\Sigma$ PUFA $* *$ & $\%$ & $40.06 \pm 1.08^{c}$ & $29.14 \pm 0.60^{\mathrm{a}}$ & $31.69 \pm 1.82^{\mathrm{b}}$ & $31.19 \pm 1.48^{\mathrm{ab}}$ & $29.30 \pm 0.81^{\mathrm{ab}}$ \\
\hline Linoleic (18:2n-6) & $\%$ & $27.31 \pm 0.91^{\mathrm{b}}$ & $19.82 \pm 0.98^{\mathrm{a}}$ & $20.83 \pm 0.93^{\mathrm{a}}$ & $20.42 \pm 0.85^{\mathrm{a}}$ & $19.58 \pm 0.78^{\mathrm{a}}$ \\
\hline Linolenic (18:3n-3) & $\%$ & $4.55 \pm 0.17^{b}$ & $1.84 \pm 0.33^{a}$ & $2.29 \pm 0.29^{\mathrm{a}}$ & $1.73 \pm 0.64^{\mathrm{a}}$ & $1.93 \pm 0.38^{\mathrm{a}}$ \\
\hline AA** $(20: 4 n-6)$ & $\%$ & $1.28 \pm 0.09^{\mathrm{a}}$ & $1.42 \pm 0.03^{\mathrm{b}}$ & $1.56 \pm 0.09^{c}$ & $1.69 \pm 0.05^{c}$ & $1.41 \pm 0.08^{\mathrm{b}}$ \\
\hline $\mathrm{EPA}^{* *}(20: 5 \mathrm{n}-3)$ & $\%$ & $0.22 \pm 0.06^{\mathrm{a}}$ & $0.26 \pm 0.02^{\mathrm{a}}$ & $0.22 \pm 0.01^{\mathrm{a}}$ & $0.22 \pm 0.01^{\mathrm{a}}$ & $0.20 \pm 0.06^{\mathrm{a}}$ \\
\hline DHA** (22:6n-3) & $\%$ & $1.46 \pm 0.09^{\mathrm{ab}}$ & $1.44 \pm 0.05^{\mathrm{ab}}$ & $1.52 \pm 0.11^{\mathrm{b}}$ & $1.44 \pm 0.15^{\mathrm{ab}}$ & $1.19 \pm 0.22^{\mathrm{a}}$ \\
\hline $\begin{array}{l}\text { CPO: Crude palm o } \\
\text { 1; PRSO: } 100 \% \text { Rul } \\
\text { SFA: Saturated fatt } \\
\text { id; EPA: Eichosape } \\
\text { alues are means } \pm\end{array}$ & 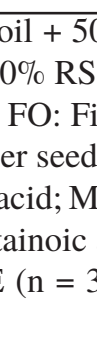 & $\begin{array}{l}\text { oil, CO: Co } \\
1 \text { with heatir } \\
\text { A: Monosa } \\
\text { d; DHA: D }\end{array}$ & $\begin{array}{l}\text { CO: } 50 \% \text { palm } \\
\text { RSO. } \\
\text { oil; RSOH: He } \\
\text { URSO: } 100 \% \\
\text { ated fatty acid; I } \\
\text { sahexanoic aci }\end{array}$ & $\begin{array}{l}\text { il + 50\% corn } \\
\text { d Rubber Seed } \\
\text { ber seed oil wi } \\
\text { FA: Polyunsatu }\end{array}$ & $\begin{array}{l}\text { hout heating. } \\
\text { ated fatty acio }\end{array}$ & : Arachidonic \\
\hline
\end{tabular}

Table 8. The chemical values of Clarias gariepinus blood fed with different lipid sources

\begin{tabular}{lccccc}
\hline \multirow{2}{*}{ Parameters } & \multicolumn{5}{c}{ Experimental diets } \\
\cline { 2 - 5 } & CPO:FO* & CPO:CO* & CPO:RSOH* & PRSO* & URSO* \\
\hline Cholesterol (mg/dL) & $133-144$ & $85-106$ & $105-108$ & $108-117$ & $84-90$ \\
HDL** (mg/dL) & $85-104$ & $78-94$ & $86-87$ & $79-86$ & $67-72$ \\
\hline *CPO:FO : 50\% palm oil + 50 \% fish oil; CPO:CO: 50\% palm oil + 50\% corn oil; CPO:RSOH: 50\% palm oil + \\
50\% RSOH; PRSO: 100\% RSOH; URSO:100\% RSO. \\
*CPO: Crude palm oil; FO: Fish oil, CO: Corn oil; RSOH: Heated rubber seed oil; RSO: Unheated rubber seed oil; \\
PRSO: 100\% Rubber seed oil with heating; URSO: 100\% rubber seed oil without heating. \\
**high density lipoprotein.
\end{tabular}

weighing $7.5 \pm 0.27 \mathrm{~g}$ per head, length $9.5 \pm$ $0.23 \mathrm{~cm}$, and reared in an aquarium with 105 $\mathrm{L}$ of water volume. Tested fish was obtained from Purwakarta, West Java. The fish were first acclimatize (feed and environment) for seven days. Stocking density used was 15 fish/aquarium. They were reared for 56 days and fed three times a day on $08.00,12.00$, and 16.00 in satiation feeding method. Sampling was carried out once every 14 days with weight, body length, and total biomass measurements. Every dead fish was weighed. The water quality was maintained and monitored in the maintenance container, a top filter, aerator set, thermostat, and thermometer installed on the inner front wall of the aquarium.

\section{Experimental parameters}

The parameters in this study consisted of chemical analysis, evaluation of feed utilization, stress indicators, and growth performance. Chemical analysis included proximate analysis of raw materials, tested feed and fish, $\mathrm{HCN}$ content analysis, and analysis of fatty acid profiles. Evaluation of feed utilization included feed conversion ratio (FCR), protein and fat retention, muscle and liver glycogen, and blood chemistry. Stress indicator parameters consisted of the metabolic stress response in the form of blood images and oxidative stress response in the form of malanodealdehyde (MDA) and superoxide dismutase (SOD). Meanwhile, growth performance parameters consisted of the amount of feed consumption, daily growth rate, and survival rate.

\section{Data analysis}

Data were analyzed using analysis of variance (ANOVA) with $95 \%$ of confidence level ( $\alpha$ : $5 \%$ ) followed by normality test and homogeneity test using SPSS 20.0. If any significant differences were found, further tests would be conducted using the Duncan method. 


\section{RESULTS AND DISCUSSION}

\section{Results}

Growth and feed performance

Based on this experiment, it was known that Clarias gariepinus in PRSO and CPO:RSOH treatments showed a decent growth and feed performance and were not statistically significant $(\mathrm{P}>0.05)$ with fish in CPO:FO and CPO:CO treatments (Table 6). Different things were shown by fish in the URSO treatment that showed lower growth performance and were statistically significantly different $(\mathrm{P}<0.05)$ from other treatments.

\section{Body fatty acids}

The results of body fatty acid analysis showed that Clarias gariepinus fed with different lipid sources had different body fatty acid compositions (Table 7). The SFA and PUFA content of fish fed with RSO based was not statistically different $(\mathrm{P}>0.05)$ from fish fed with CPO:CO. On the contrary, it is statistically different $(\mathrm{P}<0.05)$ from fish fed with CPO:FO.

\section{Blood chemistry}

The results of the blood chemistry test showed there were differences in the blood chemical value of Clarias gariepinus which was fed with different lipid sources (Table 8). Fish in CPO:RSOH and PRSO treatments had a higher range of cholesterol and HDL values compared to fish in URSO treatment.

\section{Blood profile}

The blood profile results show that Clarias gariepinus fed with different lipid sources have different blood profile (Table 9). Fish in the PRSO and CPO:RSOH treatments have a higher range of $\mathrm{Hb}, \mathrm{Ht}$, and erythrocytes and lower range of leukocytes compared to fish in the URSO treatment.

\section{MDA and SOD values}

MDA and SOD test results showed that the Clarias gariepinus in the PRSO treatment had lower MDA values and were statistically significantly different $(\mathrm{P}<0.05)$ from the fish in the URSO treatment (Table 10). Meanwhile, fish in PRSO treatment had higher SOD value and statistically significantly different $(\mathrm{P}<0.05)$ with fish in URSO treatment.

Table 9. The blood profile of Clarias gariepinus fed with different lipid sources

\begin{tabular}{cccccc}
\hline \multirow{2}{*}{ Parameters } & \multicolumn{5}{c}{ Experimental diets } \\
\cline { 2 - 6 } & CPO:FO* & CPO:CO* & CPO:RSOH* & PRSO* $^{*}$ & URSO* \\
\hline Hemoglobin $(\mathrm{Hb})(\%)$ & $10.40-11.20$ & $11.80-12.00$ & $14.00-15.00$ & $12.20-12.60$ & $10.10-10.90$ \\
Hematocrit $(\mathrm{Ht})(\%)$ & $29.70-31.60$ & $29.20-33.80$ & $36.70-42.30$ & $33.40-34.00$ & $24.80-27.90$ \\
Erythrocytes & $1.85-2.24$ & $2.06-2.09$ & $2.65-3.00$ & $2.20-2.23$ & $1.79-1.98$ \\
Leukocytes & $38.00-55.30$ & $43.60-50.70$ & $34.60-71.90$ & $46.50-52.40$ & $45.20-56.90$ \\
\hline
\end{tabular}

*CPO:FO : 50\% palm oil + 50 \% fish oil; CPO:CO: 50\% palm oil + 50\% corn oil; CPO:RSOH: $50 \%$ palm oil + 50\% RSOH; PRSO: 100\% RSOH; URSO:100\% RSO.

*CPO: Crude palm oil; FO: Fish oil, CO: Corn oil; RSOH: Heated rubber seed oil; RSO: Unheated rubber seed Oil; PRSO: 100\% Rubber seed oil with heating; URSO: 100\% rubber seed oil without heating.

Table 10. MDA and SOD tests for Clarias gariepinus fed with different lipid sources.

\begin{tabular}{cccccc}
\hline \multirow{2}{*}{ Parameters } & \multicolumn{5}{c}{ Experimental diets } \\
\cline { 2 - 6 } & CPO:FO* & CPO:CO* & CPO:RSOH* & PRSO $^{*}$ & URSO $^{*}$ \\
\hline MDA (uMol/L) & $1.26 \pm 0.01^{\mathrm{a}}$ & $1.38 \pm 0.06^{\mathrm{ab}}$ & $1.44 \pm 0.04^{\mathrm{ab}}$ & $1.70 \pm 0.02^{\mathrm{b}}$ & $3.45 \pm 0.27^{\mathrm{c}}$ \\
SOD (U/g prot) & $9.41 \pm 0.89^{\mathrm{b}}$ & $9.94 \pm 1.51^{\mathrm{b}}$ & $9.10 \pm 0.21^{\mathrm{b}}$ & $8.86 \pm 1.11^{\mathrm{b}}$ & $5.56 \pm 1.40^{\mathrm{a}}$ \\
\hline
\end{tabular}

*CPO:FO : $50 \%$ palm oil + 50 \% fish oil; CPO:CO: $50 \%$ palm oil + 50\% corn oil; CPO:RSOH: $50 \%$ palm oil + 50\% RSOH; PRSO: $100 \%$ RSOH; URSO: $100 \%$ RSO.

*CPO: Crude palm oil; FO: Fish oil, CO: Corn oil; RSOH: Heated rubber seed oil; RSO: Unheated rubber seed oil; PRSO: 100\% Rubber seed oil with heating; URSO: $100 \%$ rubber seed oil without heating. Values are means \pm $\mathrm{SE}(n=3)$. Values that share different letters in the same column are significantly different (Duncan test; $\mathrm{P}<0.05$ ). 


\section{Liver and body glycogen}

Liver and body glycogen test results showed that feeding with different feed lipid source affects fish body and liver values (Table 11). Fish in PRSO treatment have a higher body and liver glycogen values compared to fish in URSO treatment.

\section{Discussion}

Five types of tested feed were made to observe the effect of different types of raw material sources of feed lipids by using heated rubber seed oil (RSO). Based on the results of this study, it is known that the heating process of RSO using an oven at a temperature of $100^{\circ} \mathrm{C}$ with a duration of 60 minutes could reduce levels of hydrogen cyanide (HCN) in RSO up to $95 \%$ (Table 1). Rubber seeds have by-products of plant metabolites in the form of linamarin. Linamarin can form a stable complex in the form of $\mathrm{HCN}$ when it meets with the enzyme linamarase (Salimon et al., 2012). In the study of Kushayadi et al. (2019), heating at $100^{\circ} \mathrm{C}$ for 60 minutes can reduce $\mathrm{HCN}$ levels in rubber seed oil by $95 \%$. Although $\mathrm{HCN}$ can be evaporated at $26^{\circ} \mathrm{C}$, a higher temperature used to shorten the evaporation time (Nebiyu \& Getachew, 2011). The heating process did not show any effect in the form of a significant decrease in the value of fatty acids (Table 2).

Added heated RSO in feed (CPO:RSOH and PRSO) did not affect fish SR, SGR, protein retention value, and lipid retention. Tested fish in CPO:RSOH andPRSO treatments did not show SR, SGR, protein retention value, and lipid retention that were significantly different from tested fish in CPO:FO and CPO:CO treatments (Table 6). SGR is influenced by the amount of nutrients that can be retained by the body. Suprayudi et al. (2016) and Fawole et al. (2016) also showed that the decrease of $\mathrm{HCN}$ in feed raw materials was able to maintain the value of protein retention and lipid retention in tilapia and rohu. The SR, SGR, protein retention value, and lipid retention in URSO treatments were lower and significantly different from other treatments. The high level of $\mathrm{HCN}$ in the URSO treatment is thought to be the cause of the nutrients absorption inhibition. The decreases of SR and SGR fish because the nutrients derived from feed were insufficient for body maintenance. If this continues, the fish will utilize stored nutrients as energy to maintain the body so that the amount of stored nutrients become lower. The inhibition of nutrient absorption cause fish require more amount of feed to complete their nutrients need so that the ratio of FCR in the URSO treatment becomes greater. The inhibition of nutrient absorption is caused by inactive zymogens. $\mathrm{HCN}$ is able to block the active sites of enzymes, especially peptidase and lipase so that the enzyme activity decreases. Enzymes play a role in cutting complex nutrient bonds into simple bonds that are easily digested by the intestine (NRC, 2011). The same thing happened in the Komariyah et al. (2014), showed the value of SR, SGR, protein retention value, and lipid retention of fish decreased with increasing HCN concentrations in feed.

In addition to affecting SR and SGR, the amount of nutrients that are retained also affects the fatty acid profile of the fish's body. This can be seen from the content of saturated fatty acids (SFA) and polyunsaturated fatty acids (PUFA) in the tested fish body fatty acid profile (Table 7). The SFA and PUFA content of tested fish fed with heated RSO-based feed is relatively not significantly different from tested fish fed with palm oil-based feed. $\mathrm{Ng}$ et al. (2013) study also showed that tilapia fed with linseed oil and palm oil had PUFA values that were relatively similar to tilapia which were fed with palm oil based and

Table 11. Liver glycogen and body glycogen value for Clarias gariepinus fed with different lipid sources.

\begin{tabular}{lccccc}
\hline \multirow{2}{*}{ Parameters } & \multicolumn{4}{c}{ Experimental diets } \\
\cline { 2 - 5 } & CPO:FO* & CPO:CO* & CPO:RSOH* & PRSO* & URSO* \\
\hline Liver glycogen (mg/g) & $7.98 \pm 0.03^{\mathrm{a}}$ & $5.05 \pm 0.62^{\mathrm{ab}}$ & $3.49 \pm 0.33^{\mathrm{ab}}$ & $3.13 \pm 0.55^{\mathrm{b}}$ & $2.59 \pm 0.31^{\mathrm{c}}$ \\
Body glycogen (mg/g) & $3.83 \pm 0.26^{\mathrm{a}}$ & $1.90 \pm 0.01^{\mathrm{b}}$ & $1.71 \pm 0.01^{\mathrm{b}}$ & $1.74 \pm 0.01^{\mathrm{b}}$ & $1.66 \pm 0.00^{\mathrm{b}}$ \\
\hline *CPO:FO : 50\% palm oil + 50 \% fish oil; CPO:CO: 50\% palm oil + 50\% corn oil; CPO:RSOH: $50 \%$ palm oil + \\
50\% RSOH; PRSO: 100\% RSOH; URSO:100\% RSO. \\
*CPO: Crude palm oil; FO: Fish oil, CO: Corn oil; RSOH: Heated rubber seed oil; RSO: Unheated rubber seed \\
oil; PRSO: 100\% Rubber seed oil with heating; URSO: 100\% rubber seed oil without heating. Values are means \pm \\
SE ( $n=3$ ). Values that share different letters in the same column are significantly different (Duncan test; P<0.05).
\end{tabular}


showed the same weight gain between treatments. This indicates that RSO-based feeds can provide the same profile of body fatty acids and growth as other vegetable oil-based feeds.

Nutrients absorbed by the body will be circulated in the blood. This can be seen in the difference of blood chemical values (cholesterol and HDL) in each treatment (Table 8). Tested fish in the PRSO and CPO:RSOH treatments had higher ranges of cholesterol and HDL values compared to tested fish in the URSO treatment. The low amount of nutrients absorbed is thought to be the cause of the low range cholesterol and HDL values of tested fish in the URSO treatment. The main function of HDL is to transport blood lipid from body tissue to the liver (Luo et al. 2014). According to Stepanowska et al. (2006) fish with deficient nutrient conditions tend to experience decreased blood lipid concentrations. The low cholesterol and HDL values are also related to the low protein retention value of the URSO treatment resulting in a low apoprotein value. Apoprotein is an albumin group that is used to circulate lipid in the bloodstream. As an insoluble compound in polar solvents, lipids need apoprotein to emulsify lipids in the form of lipoproteins and circulate in the bloodstream (NRC, 2011). Besides being influenced by the amount of nutrients absorbed, blood chemical levels are also influenced by the feed raw material used. Some previous studies stated that blood cholesterol levels are closely related to cholesterol in the feed consumed. Suprayudi et al. (2016) study's also mentioned that fish fed with rubber seed based on low HCN showed an increase of cholesterol levels in blood plasma. The presence of $\mathrm{HCN}$ in blood can cause cholesterol and HDL to be low (Aviram et al., 2000; Brites et al., 2017).

HCN that enters the body can cause metabolic stress in fish. The effect of metabolic stress in fish can be seen with secondary responses in fish blood profile (Wahyu et al., 2015). There is no significant differences in erytrocytes, leukocytes, $\mathrm{Hb}$ and $\mathrm{Ht}$ value found between the CPO:RSOH and PRSO treatments with the CPO:FO and CPO:CO treatments (Table 9). The same thing was found in several studies (Deng et al., 2015; Fawole et al., 2016; Suprayudi et al., 2016) with the results of fish fed with low rubber seed based HCN not showing any difference in erytrocytes and leukocytes values. However, the URSO treatment showed different result, which were higher leukocytes value and lower erytrocytes value when compared to other treatments (Table 9). Suprayudi et al. (2016) suggested that the provision of high seed-based rubber $\mathrm{HCN}$ can increase leukocytes and reduce human resources in fish. Stressful conditions in fish can suppress the health conditions of fish and fish are increasingly vulnerable to disease. The leukocytes in fish is the first level of protective response to infection or tissue damage due to stress oxydative (Ezike et al., 2019).

The low proportion of erytrocytes can be caused by the lipid peroxidation process. Lipid peroxidation that occursin the blood cell membrane will disrupt the permeability of blood cells so the blood cells become lysis. Simultaneously with the lipid peroxidation process a malanodealdehyde (MDA) compound is formed as the final product of the lipid peroxidation process on the cell membrane (Fawole et al., 2016). Clarias gariepinus which were given URSO treatment had higher MDA levels and were significantly different from other treatments. In contrast, the tested fish treated with CPO: RSOH and PRSO had MDA levels that did not differ significantly from CPO: FO and CPO: CO (Table 10). MDA is known as one of the markers for oxidative stress (Arinola et al., 2010; Nwani et al., 2010) related to stress caused by an increase in reactive oxygen species (ROS) including HCN (Nwani et al., 2010; Lushchak, 2011; Deng et al., 2015; Fawole et al., 2016). According to David and Kartheek (2015) only with HCN levels of $0.2 \mathrm{mg} / \mathrm{L}$ in water can increase MDA in blood vessels.

When oxidative stress occurs, the body will produce antioxidants as a form of protection against free radical damage. Antioxidants are substances that have the task of delaying or preventing cells from being oxidized (Franco \& Martenez-Pinilla, 2017). Some of the antioxidant enzymes produced by the body are superoxide dismutase (SOD), glutathione peroxidase, and catalase (Sharma et al., 2014). Tested fish treated with CPO:RSOH and PRSO showed SOD values that were not significantly different from CPO:FO and CPO:CO treatments, while tested fish treated with URSO had lower SOD values and were significantly different from other treatments (Table 10). The low SOD value and high MDA value in fish treated with URSO indicates the fish experienced oxidative stress. According to Yang et al. (2015), low levels of SOD and high MDA 
are a dangerous conditions for aquatic organisms and can reduce growth rates. SOD is an enzyme that acts as an intracellular antioxidant. SOD will convert free radicals into hydroperoxide $\left(\mathrm{H}_{2} \mathrm{O}_{2}\right)$. Low levels of SOD can be caused by increased lipid peroxidation due to the amount of free radicals absorbed by the body. The higher SOD enzyme activity indicates the lower lipid oxidation products that occur (Johannson et al., 2018).

The energy used to overcome oxidative stress and release SOD is the stored energy called glycogen. Tested fish treated with URSO had lower levels of liver glycogen and were significantly different from other treatments (Table 11). This showed that there were a decrease in glycogen value along with an increase in HCN consumption. Also a decrease in liver glycogen values that decreased significantly in rats with high levels of oxidative stress (Abdullah \& Salimon, 2010). Decreased glycogen levels are caused by an increase in fish glucose requirements in the $\mathrm{HCN}$ detoxification process, so that more glycogenolysis processes occur in the liver and muscle of the fish (Suprayudi et al., 2015).

\section{CONCLUSIONS}

Based on this study it can be concluded that heating can reduce $\mathrm{HCN}$ levels in rubber seed oil by $95 \%$. Giving $100 \%$ heated rubber seed oil (PRSO) has no side effects on growth performance and feed intake in Clarias gariepinus. Thus, $100 \%$ of heated rubber seed oil can be used as a raw material source of feed lipid substitute for corn oil and palm oil.

\section{REFERENCES}

Abdullah BM, Salimon J. 2010. Toxicity study of Malaysian rubber Hevea brasiliensis seed oil as rats and shrimp tests. Asian Journal of Biochemistry 5: 33-39.

[AOAC] Association of Official Analytical Chemists. 2012. Official Methods of Analysis of AOAC Intl. 19th ed. Maryland (US): Association of Official Analytical Chemists.

Arinola OG, Akinosun MO, Oniye HAD. 2010. Metal binding proteins and immunoglobulin classes in the serum of Nigerian cassava processors. Nature Science 8: 27-34.

Aviram M, Dornfield L, Rosenblat M, Volkova N, Kaplan M, Coleman R, Hayek T, Presser
D, Fuhrman B. 2000. Pomegranate juice consumption reduces oxidative stress, artheriogenic modifications to LDL, and platelet aggregation: Studies in humans and artheroscleoteric apolipoprotein E. The American Journal of Clinical Nutrition 71: 1062-1076.

Bami ML, Kamarudin MS, Saad CR, Arshad A, Ebrahim M. 2017. Effect of palm oil products on growth performance, body composition and fatty acid profile of juvenile Malaysian mahseer Tor tambroides. Journal of Oil Palm Research 29: 287-400.

Brites F, Martin M, Guillas I, Kontush. 2017. Antioxidative activity on high density lipoprotein (HDL): Mechanistic insights into potential clinical benefit. BBA Clinical 8: 66-77.

David M, Kartheek RM. 2015. In vivo studies on hepatorenal impairments in freshwater fish Cyprinus carpio following exposure to sublethal concentrations of sodium cyanide. Environmental Science and Pollution Research 23: 722-733.

Deng JM, Wang Y, Chen LQ, Mai KS, Wang Z, Zhang X. 2015. Effect of replacing plant protein with rubber seed meal on growth, nutrient utilization and blood biochemical parameters of tilapia (Oreochromis niloticus $\times$ O. aureus). Aquaculture nutrition 23: 30-39.

Directorate General of Plantations. 2010. Indonesian Plantation Production Statistics 2009-2011. Indonesian Ministry of Agriculture, Jakarta.

Dowd MK, Deborah LB, William RM, Campbell BT, Bourland FM, Gannaway JR, Glass KM, Zhang J. 2010. Fatty acid profiles of cottonseed genotypes from the national cotton variety trials. The Journal of Cotton Science 14: 64-73.

Ezike CO, Echor FO, Uwadiegwu NC, Okechukwu GE. 2019. Haematology, Oxidative Stress and Micronuclei Frequency of Clarias gariepinus Exposed to Glyphosate based Herbicide Glycot ${ }^{\circledR}$ GBHG. International Journal of Advanced Fisheries and Aquatic Science 4: 106-121.

Fawole FJ, Sahu NP, Jain KK, Gupta S, Rajendran KV, Shamna N, Poojary N. 2016. Haematobiochemical, non-specific immunity, antioxidant capacity and histopathological changes in Labeo rohita fingerlings fed 
rubber protein isolate. Fish Physiology and Biochemistry 43: 677-690.

Franco R. Martínez-Pinilla E. 2017. Chemical rules on the assessment of antioxidant potential in food and food additives aimed at reducing oxidative stress and neurodegeneration. Food Chemistry 235: 318-323.

Hwang J. 2009. Diets with corn oil and/or low protein increase acute acetaminophen hepatotoxicity compared to diets with beef tallow in a rat model. Nutrition Research and Practice 3: 95-101.

Johannson OE, Giacomin M, Henrique HS, Campos DF, Mota SB, Caldas WDH, Baptista R, Wood CM, Val VMFM, Val AL. 2018. Does hypoxia or different rates of reoxygenation after hypoxia induce an oxidative stress response in Cyphocharax abramoides (Kner, 1858), a charcaid fish of the Rio Negro. Comparative Biochemistry and Physiology 224: 53-67.

Komariyah S, Suprayudi MA, Jusadi D. 2014. Preliminary study of rubber seed Hevea brasiliensis oil utilization for tilapia diet. Jurnal Akuakultur Indonesia 13: 61-67.

[KKP] Kementerian Kelautan dan Perikanan. 2017. Dashboard Produksi Perikanan dan Kelautan Satu Data. Diakses 19 Maret 2019.

Kumar A, Sharma S. 2011. Potential non-edible oil resources as biodiesel feedstock: An Indian perspective. Renewable and Sustainable Energy Reviews 15: 1791-1800.

Kushayadi AG, Suprayudi MA, Jusadi D, Fauzi IA. 2019. Evaluation of rubber seed oil as lipid source in red tilapia Oreochromis sp. diet. Aquaculture Research 51: 114-123.

Luo L, Xue M, Vachot C, Geurden I, Kaushik S. 2014. Dietary medium chain fatty acids from coconut oil have little effects on postprandial plasma metabolite profiles in rainbow trout Oncorhynchus mykiss. Aquaculture 420: 2431.

Lushchak VI. 2011. Environmentally induced oxidative stress in aquatic animals. Aquatic Toxicology 101: 13-30.

Nebiyu A, Getachew E. 2011. Soaking and drying of cassava roots reduced cyanogenic potential of three cassava varieties at Jimma Southwest Ethiopia. African Journal of Biotechnology 10: 13465-13469.

Ng KW, Chong CW, Wang Y, Romano N. 2013. Effects of dietary fish and vegetable oils on the growth, tissue fatty acid composition, oxidative stability and vitamin E content of red hybrid tilapia and efficacy of using fish oil finishing diets. Aquaculture 372: 97-110.

NRC. 2011. Nutrien Requirement of Fish and Shrimp. National Academy Press. Washington D.C. National Research Council. 102 pp.

Nwani CD, Lakra WS, Nagpure NS, Kumar R, Kushwaha BSK, Srivastava T. 2010. Toxicity of the herbicide atrazine: effects on lipid peroxidation and activities of antioxidant enzymes in the freshwater fish Channa punctatus (Bloch). International. Journal of Enviromental Resources and Public Health 7: 3298-3312

Orsavova J, Misurcova L, Ambrozova J, Vicha R, Micek J. 2015. Fatty acids composition of vegetable oils and its contribution to dietary energy intake and dependence of cardiovascular mortality on dietary intake of fatty acids. International Journal of Molecular Sciences 16: 12871-12890.

Ortiz MR, Tomas VA, Rodriguez BD, Martinez LS, Perez JA, Jover M, Lorenzo A. 2017. Replacement of fish oil with vegetable oil blends in feeds for greater amberjack Seriola dumerili juveniles: Effect on growth performance, feed efficiency, tissue fatty acid composition and flesh nutritional value. Aquaculture Nutrition 24: 605-615.

Salimon J, Mudhaffar B, Abdullah, Salih N. 2012. Rubber seed Hevea brasiliensis oil toxicity effect and linamarin compound analysis. Lipids in Health and Disease 11: 1-8.

Shahrooz R, Naser A, Nasim J, Ali K, Reza J, Ali K. 2018. Effects of fish oil replacement with vegetable oils in rainbow trout Oncorhynchus mykiss fingerlings diet on growth performance and foregut histology. Turkish Journal of Fisheries and Aquatic Sciences 18: 825-832.

Sharma BB, Saha RK, Saha H. 2014. Effects of feeding detoxified rubber seed meal on growth performance and haematological indices of Labeo rohita (Hamilton) fingerlings. Animal Feed Science and Technology 193: 84-92.

Stepanowska K, Nedzarek A, RakusaSuszczewski S. 2007. Effects of starvation on the biochemical composition of blood and body tissue in the Antartic fish Notothenia coriiceps (Richardson, 1844) and excreted metabolic products. Polar Bioscience 20: 4654.

Suprayudi MA, Irawan WS, Utomo NBP. 2014. Evaluation of incubated defatted rubber seed 
meal with sheep rumen liquor for Pangasius diet. Jurnal Akuakultur Indonesia 13: 146151.

Suprayudi MA, Inara C, Ekasari J, Priyoutomo N, Haga Y, Takeuchi T, Satoh S. 2015. Preliminary nutritional evaluation of rubber seed and defatted rubber seed meals as plant protein sources for common carp Cyprinus carpio L. juvenile diet. Aquaculture Research 46: 2972-2981.

Suprayudi MA, Alim S, Fauzi IA, Ekasari J, Setiawati, Junior MZ, Tacon AGJ. 2016. Evaluation of hydrolysed rubber seed meal as a dietary protein source for Nile tilapia Oreochromis niloticus L. Aquaculture Research 48: 3801-3808.

Syamsunarno MB, Sunarno MTD. 2014. Rubber seed Hevea brasiliensis as a candidat of fish feed ingradient. Jurnal Ilmu Pertanian dan Perikanan Desember 3: 135-142.

Takeuchi T. 1988. Laboratory work chemical evaluation of dietary nutriens. In: Watanabe T (ed). Fish Nutrition and Mariculture. Tokyo: Department of Aquatic Bioscience. Tokyo University of Fisheries. JICA. 179-226.
Watanabe T. 1988. Fish Nutrition and Mariculture. JICA Text Book the General Aquaculture of Biosciences. Tokyo University of Fisheries. $233 \mathrm{pp}$.

Wahyu, Supriyono E, Nirmala K, Harris E. 2015. The effect of fish density during transportation on hematological parameters, blood $\mathrm{pH}$ value and survival rate of juvenile snakeheads Channa striata (Bloch, 1793). Indonesian Journal of Ichthyologi 15: 165-177.

Widyarani, Ratnaningsih E, Sanders JPM, Bruins ME. 2014. Biorefinery methods for separation of protein and oil fractions from rubber seed kernel. Industrial Crops and Products 62: 323332.

Widyarani, Coulen SCW, Sanders JPM, Bruins ME. 2016. Valorisation of proteins from rubber tree. Waste and Biomass Valorization 8: 1027-1041.

Yang SP, Liu HL, Wang CG, Yang WP, Sun CB, Chan SM. 2015. Effect of oxidized fish oil on growth performance and oxidative stress of Litopeneaus vannamei. Aquaculture Nutrition 21: 121-127. 